\title{
Therapeutic Management of Bacterial Pneumonia in Goats in Durg District of Chhattisgarh State, India
}

\author{
Rashmi S. Kashyap ${ }^{1 *}$, H. K. Ratre ${ }^{2}$, J. Singh ${ }^{3}$, Rukmani Dewangan ${ }^{4}$, C. Sannat ${ }^{5}$, \\ R. L. Rakesh ${ }^{1}$, S. Chandrakar ${ }^{3}$, S. Roy ${ }^{1}$ and S. L. Ali ${ }^{1}$
}

${ }^{1}$ Department of Veterinary Medicine, ${ }^{2}$ Department of Teaching Veterinary Clinical Complex, ${ }^{3}$ Department of Wildlife Health Centre, ${ }^{4}$ Department of Veterinary Surgery and Radiology, ${ }^{5}$ Department of Veterinary Microbiology, College of Veterinary Science \& A. H., Anjora, Durg, Chhattisgarh, India

*Corresponding author

\section{A B S T R A C T}

\section{Keywords}

Amoxicillinsulbactum, Antibiotics, Bacterial pneumonia, Ceftiofur sodium

Article Info

Accepted:

04 November 2019

Available Online:

10 December 2019
The present study was conducted to study the therapeutic management of bacterial pneumonia in goats using different antibiotic protocols. A sum of 24 goats of above 1 years of age was divided into 4 groups consisting 6 numbers of animals each. Group I was kept as control and other 3 treatment groups (Group II, III and IV) consisted of animals showing clinical signs of pneumonia. These animals were treated with Ceftiofur sodium (Group II) @ $1.1 \mathrm{mg} / \mathrm{kg}$, Amoxicillin and sulbactum combination (Group III) @ 11-22 mg/kg and Enrofloxacin (Group IV) @2.5-5 $\mathrm{mg} / \mathrm{kg}$ through intramuscular route for five consecutive days along with the supportive therapy. The therapeutic efficacy of different antibiotic protocol was compared on the basis of the recovery of clinico-physiological signs and haematobiochemical parameters. The highest recovery was observed in the group treated with ceftiofur sodium. Therefore, it can be concluded that the administration of ceftiofur sodium was more efficacious as compared to enrofloxacin and amoxicillin and sulbactum combination for treatment of bacterial pneumonia in goats.

\section{Introduction}

Goat is among one of the most important livestock securities to millions of marginal and small farmers and agricultural labourers (Kumar, 2007). In a country like India, sheep and goat play a vital role in the economy and upliftment of poor, deprived, backward classes and landless labours (Chakraborty et al., 2014). Among the notable diseases of goat, pneumonia, enteritis, different respiratory and gut associated illness are considered as 
common throughout the world which leads to an increase in production costs with expensive treatments. Bacterial infections of the respiratory tract may be primary occurring in healthy individuals or secondary to a large number of conditions which depress resistance of the animal. Pneumonia is a leading cause of economic losses in the ruminant industry throughout the world (Yener et al., 2009) and among various types of pneumonia, bacterial bronchopneumonia due to Pasteurella spp. and viral pneumonia due to bluetongue, PPR and pox viruses are most widely prevalent (Woldemeskel et al., 2002). The bacteria are normal flora of the respiratory tract of goats (Emikpe et al., 2009) which can be pathogenic when the animal is exposed to stressful and adverse conditions. Bekele et al., (1992), Garedew et al., (2010) and Kumar et al., (2012) reported that Streptococcus pneumoniae, commensal bacteria of the nasopharynx of animals associated with a majority of cases of morbidity and mortality in young lambs due to pneumonia. The signs of pneumonia in infected goat include fever, mucopurulent nasal discharge and depression dyspnea, abdominal respiration, cough, pulmonary crackling and nasal exudates (Ackermann et al., 2000). Pneumonia is usually associated with toxemia and septicemia which can alter the hematobiochemical profiles of infected animals.

Antimicrobial therapy is considered as an important and reliable tool for treating bacterial infections in both humans and animals and therefore the optimal choice of the effective antibiotic results in minimizing morbidity and mortality rates associated with such pathogens (Travers and Barza, 2002). Antibiotic sensitivity test should be performed before choicing antibiotic therapy (Ramya, 2014). In-vitro antibiotic sensitivity pattern of isolates was studied by Aher et al., (2012) which was obtained from the respiratory tract of apparently healthy and sick goats against commonly used antibiotics and observed that Staphylococcus isolates were sensitive to enrofloxacin, gentamicin, ciprofloxacin, pefloxacin, oxacillin, cefepime, amoxicillin, amikacin, carbenicillin, ampicillin, streptomycin, methicillin, ceftriaxone and penicillin-G, while Bacillus spp. were sensitive to tetracycline, chloramphenicol, erythromycin, enrofloxacin, gentamicin, ciprofloxacin, pefloxacin, oxacillin, cefepime, amoxicillin, amikacin, sulfadiazine, ampicillin, streptomycin, co-trimoxazole and ceftriaxone. It is a fact that small scale and marginal landless farmers of Chhattisgarh state are keeping goats for their livelihood. Disease like pneumonia may cause high rate of mortality thereby causing huge financial loss to goat keepers. Pneumonia especially of bacterial origin is very common and may cause high mortality rate in goats. Reports regarding therapeutic management of pneumonia in goats by these antibiotics viz., Ceftiofur Enrofloxacin Amoxicillin and sulbactum are limited; therefore, the present study was undertaken to compare therapeutic efficacy of different antibiotic protocol on the basis of the recovery of clinico-physiological signs and haemato-biochemical parameters.

\section{Materials and Methods}

A total of 24 goats were selected and divided into 4 groups with each group having 6 animals. Group I was kept as control which comprised of healthy goats and other 3 (treatment) groups (Group II, III and IV) comprised of animals showing clinical signs of pneumonia. All animals selected were above 1 year of age. Ceftiofur sodium for Group II was selected on the basis of practical efficacy of drug in large animal respiratory diseases and the other two antibiotics used in this study i.e. Amoxicillin and sulbactum combination for Group III and Enrofloxacin for Group IV were selected on the basis of 
antibiotic sensitivity test. Amoxicillin and sulbactum combination @11-22 mg/kg b.wt., Enrofloxacin @ 2.5-5 mg/kg b.wt. and Ceftiofur sodium @1.1-2.2 mg/kg b.wt.was administered for a period of five consecutive days through intramuscular route. In all treatment groups, the supportive therapy including meloxicam and paracetamol combination@1 ml/10 Kg b.wt., pheniramine (antihistaminic) @ 0.5-1 ml/ kg b.wt. and tribivet @1-2 ml were given. There was no treatment given to the control group. For comparison of different therapeutic management, clinico-physiological were recorded from day 0 up to day 7 and haematobiochemical parameters were recorded at day 0 and day 7. The clinico-physiological parameter like nasal discharge, rectal temperature, heart rate and respiratory rate were recorded.

For haemato-biochemical parameters, blood samples were collected at day 0 and day 7 . A total of $5 \mathrm{ml}$ blood was collected from juglar vein of each goat. About $2 \mathrm{ml}$ blood was collected in EDTA vial (Peerless Biotech Pvt. Ltd, India) for estimation of haematological parameters viz., Hb, TEC, PCV and TLC, while $3 \mathrm{ml}$ blood was collected in serum tubes (Peerless Biotech Pvt. Ltd, India) for harvesting serum for estimation of biochemical parameters like AST, ALT, TSP, Albumin and Serum Glucose. The globulin was calculated by subtracting the values of TSP and Albumin and then A/G ratio was also obtained. The haematological parameters were estimated using MS39 Semi Automatic Haematological Analyser (Melet Schloesing Aboratoires). The biochemical parameters was estimated by diaSIL-100 SYSTRONICS semiauto analyzer using AUTOSPAN ${ }^{\circledR}$ liquid Gold Total Protein kit of ARKRAY healthcare Pvt. Ltd. The data obtained was analyzed statistically by using CRD as per the methods suggested by Snedecor and Cochran (1994) by using IBM SPSS statistics 20.

\section{Results and Discussion}

\section{Clinico-physiological parameters}

The effects on Clinico-physiological parameters before and after different therapeutic management in goats (Mean $\pm \mathrm{S}$. E.) are shown in Table 1.

\section{Nasal discharge}

It was absent in group I and present in all goats of the treatment group (II, III and IV) on day 0 . On day 7 , nasal discharge was absent in all goats of Group II whereas it was present in few goats of group III and IV. The presence of nasal discharge may indicate any disease in the upper or lower respiratory tract.

\section{Rectal temperature}

On day 0 , the treatment groups II, III and IV showed significantly $(\mathrm{p}>0.05)$ increased values of rectal temperature as compared to group I (healthy control). However, the mean values of rectal temperature were significantly lower in group I and II as compared to group III and IV on day 7. The mean values of temperature were non-significantly lower in group IV as compared to group III on day 7 . The fever which is observed in the pneumonic cases in goats is one of the common and constant finding in natural infections (Rahman and Singh, 1990).

\section{Heart rate}

In all the three treatment groups II, III and IV showed significantly $(p>0.05)$ increased values of heart rate as compared to group I (healthy control) on day 0 . However, on day 7 , there was non- significant difference between all the groups. In the present study, before treatment there was increase in heart rate which was within normal range after treatment. 


\section{Respiration rate}

In treatment groups II, III and IV on day 0, there was significantly $(p>0.05)$ increased in respiration rated as compared to group I (healthy control). However, the mean values of respiration rate were non-significantly higher in group I as compared to group II, III and IV on day 7.

\section{Haematological parameters}

The effects on haematological parameters before and after different therapeutic management in goats (Mean \pm S. E.) are shown in Table 2. In the present study, haematological findings revealed significantly decreased values of hemoglobin, PCV, TEC and lymphocytes and increased in values of TLC and neutrophils all pneumonic goats during initial period before initiation of therapy. Comparison between groups revealed a significantly lower value of haemoglobin, PCV, TEC and lymphocytes whereas higher values of TLC and neutrophils in II, III and IV as compared to group I on both day 0 . However, the mean values of hemoglobin, PCV, TEC and lymphocytes were significantly higher and the mean values of TLC and neutrophils were lower in Group II and IV as compared to group III on day 7. However, most of the haematological parameters were found to return the normal level by the end of the observation period. Reduction of hemoglobin synthesis and production of microcytic hypochromic RBCs due to decreased iron transfer to developing erythroid cells in bone marrow has been assumed to cause anemia (Aytekin et al., 2011). Saleh and Allam (2014) reported that total leukocytic count was increased in acute inflammatory diseases particularly those due to bacterial infections In the present study, there was increase TLC which is suggestive of tissue injury or any inflammation (Jarikre $e t$ al., 2016). Similar, findings have also been reported by Mandal et al., (2017) regarding changes in total leucocyte count. This could be attributed to that infectious agents and products of tissue injury stimulate a variety of cells to release growth factors, cytokines, and other mediators of inflammation that act as prompt stimuli and are all interrelated in causing the increase in total white blood cells count and more production, proliferation, maturation and bone marrow release of mature and immature neutrophils (Sayed et al., 2002).

Mandal et al., (2017) also revealed a significant decrease in the mean hemoglobin, TEC, PCV values in goats affected by respiratory disease as compared to healthy goats.

\section{Biochemical parameters}

The effects on biochemical parameters before and after different therapeutic management in goats (Mean \pm S. E.) are shown in Table 3. In the present study, the serum glucose values were decreased in all pneumonic goats which increased significantly $(p<0.01)$ by the end of the observation period. Serum glucose level decreases as a consequence of bacterial infection, the animals remained off-fed condition or in reduced appetite which contributes to decrease serum glucose level in affected goats. The restoration of glucose values towards normal range by the end of observation period might be due to decrease in bacterial population and restoration of normal appetite. In the present study, there was significant $(\mathrm{p}<0.01)$ decrease in total serum protein, albumin and $\mathrm{A} / \mathrm{G}$ ratio whereas globulin, AST and ALT were increased in all pneumonic goats during initial period before initiation of therapy. However, most of the biochemical parameters were found to return the normal level by the end of the observation period. 
Table.1 Mean \pm S.E. value of clinico-physiological parameters before and after different therapeutic management in goats

\begin{tabular}{|c|c|c|c|c|c|}
\hline Clinical sign & Day & Group I & Group II & Group III & Group IV \\
\hline Nasal Discharge & 0 & Absent & Present & Present & Present \\
\cline { 2 - 6 } & 7 & Absent & Abent & Present in few & Present in few \\
\hline Temperature & 0 & $102.90 \pm 0.18^{\mathrm{b}}$ & $104.83 \pm 0.22^{\mathrm{a}}$ & $104.87 \pm 0.19^{\mathrm{a}}$ & $104.87 \pm 0.13^{\mathrm{a}}$ \\
\cline { 2 - 6 } & 7 & $102.67 \pm 0.17^{\mathrm{b}}$ & $102.73 \pm$ & $103.17 \pm$ & $102.93 \pm 0.10^{\mathrm{ab}^{* *}}$ \\
& & & $0.10^{\mathrm{b}^{* *}}$ & $0.10^{\mathrm{a}^{* *}}$ & \\
\hline Respiration rate & 0 & $25.83 \pm 0.83^{\mathrm{b}}$ & $39.17 \pm 2.07^{\mathrm{a}}$ & $42.67 \pm 0.99^{\mathrm{a}}$ & $41.00 \pm 1.69^{\mathrm{a}}$ \\
\hline / per min & 7 & $26.17 \pm 0.48$ & $26.17 \pm 0.48$ & $25.00 \pm 0.45^{* *}$ & $25.33 \pm 0.33^{* *}$ \\
\hline Heart rate & 0 & $101.33 \pm 1.52^{\mathrm{b}}$ & $128.67 \pm 2.11^{\mathrm{a}}$ & $130.67 \pm 3.21^{\mathrm{a}}$ & $128.00 \pm 3.99^{\mathrm{a}}$ \\
\hline (beats/minute) & 7 & $103.00 \pm 1.91$ & $103.00 \pm$ & $102.67 \pm$ & $102.33 \pm 1.96^{* *}$ \\
& & & $1.99^{* *}$ & $2.04^{* *}$ & \\
\hline
\end{tabular}

* Significantly different from base values $(\mathrm{p}<0.05)$

** Significantly different from base values $(\mathrm{p}<0.01)$

${ }^{a b c}$ Means within the same row with different superscripts differ $(\mathrm{P}<0.05)$

Table.2a Mean \pm S.E. value of haematological parameters before and after different therapeutic management in goats

\begin{tabular}{|c|c|c|c|}
\hline \multirow[t]{2}{*}{ Parameters } & \multirow[t]{2}{*}{ Groups } & \multicolumn{2}{|c|}{ Day } \\
\hline & & 0 (before treatment) & 7 (after treatment) \\
\hline \multirow{4}{*}{$\begin{array}{l}\text { Hemoglobin } \\
\text { (g/dl) }\end{array}$} & I & $9.76 \pm 0.12^{\mathrm{a}}$ & $9.80 \pm 0.12^{\mathrm{a}}$ \\
\hline & II & $8.48 \pm 0.07^{b}$ & $9.39 \pm 0.07^{b * *}$ \\
\hline & III & $8.45 \pm 0.27^{b}$ & $8.91 \pm 0.18^{c}$ \\
\hline & IV & $8.59 \pm 0.03^{b}$ & $9.15 \pm 0.06^{b c^{* * *}}$ \\
\hline \multirow{4}{*}{$\begin{array}{c}\text { Total } \\
\text { Erythrocyte } \\
\text { Count }(10 \% / \mu \mathrm{l})\end{array}$} & I & $8.65 \pm 0.07^{\mathrm{a}}$ & $8.73 \pm 0.06^{\mathrm{a}}$ \\
\hline & II & $6.97 \pm 0.12^{b}$ & $8.52 \pm 0.06^{b * *}$ \\
\hline & III & $7.12 \pm 0.15^{b}$ & $8.23 \pm 0.03^{\mathrm{c}^{* * *}}$ \\
\hline & IV & $7.19 \pm 0.10^{b}$ & $8.30 \pm 0.04^{c^{* * *}}$ \\
\hline \multirow{4}{*}{$\begin{array}{l}\text { Packed cell } \\
\text { volume (\%) }\end{array}$} & I & $29.19 \pm 0.37^{\mathrm{a}}$ & $29.30 \pm 0.39^{a}$ \\
\hline & II & $25.46 \pm 0.21^{b}$ & $28.14 \pm 0.21^{b^{* * *}}$ \\
\hline & III & $25.37 \pm 0.82^{b}$ & $26.76 \pm 0.54^{c}$ \\
\hline & IV & $25.76 \pm 0.10^{b}$ & $27.42 \pm 0.18^{b c^{* *}}$ \\
\hline \multirow{4}{*}{$\begin{array}{l}\text { Total leucocyte } \\
\text { count }\left(10^{3} / \mu \mathrm{l}\right)\end{array}$} & I & $7458.67 \pm 354.26^{b}$ & $7510.33 \pm 342.86$ \\
\hline & II & $12316.67 \pm 475.49^{a}$ & $7574.83 \pm 233.70 * *$ \\
\hline & III & $11845.00 \pm 494.50^{a}$ & $7830.00 \pm 271.00 * *$ \\
\hline & IV & $12196.00 \pm 294.96^{a}$ & $7589.00 \pm 328.35 * *$ \\
\hline
\end{tabular}

* Significantly different from base values $(\mathrm{p}<0.05)$

** Significantly different from base values $(\mathrm{p}<0.01)$

Values with different superscripts differ significantly $(\mathrm{p}<0.05)$ among the groups 
Table.2b Mean \pm S.E. value of haematological parameters (Total Differential leukocyte count $(\%)$ ) before and after different therapeutic management in goats

\begin{tabular}{|c|c|c|c|c|}
\hline \multicolumn{2}{|c|}{ Parameters } & Group & 0 day & 7 day \\
\hline \multirow{20}{*}{$\begin{array}{c}\text { DLC } \\
\%\end{array}$} & \multirow{4}{*}{ Neutrophils } & I & $37.67 \pm 1.80^{b}$ & $37.00 \pm 1.80^{b}$ \\
\hline & & II & $59.17 \pm 0.98^{a}$ & $37.83 \pm 1.22^{\mathrm{ab}_{*} * *}$ \\
\hline & & III & $59.50 \pm 0.99^{a}$ & $43.83 \pm 2.06^{\mathrm{a} * *}$ \\
\hline & & IV & $58.33 \pm 1.12^{a}$ & $39.66 \pm 1.47^{\mathrm{ab}_{* *} *}$ \\
\hline & \multirow{4}{*}{ Lymphocytes } & I & $53.00 \pm 1.77^{a}$ & $54.67 \pm 1.69$ \\
\hline & & II & $32.33 \pm 1.23^{b}$ & $53.00 \pm 1.39 * *$ \\
\hline & & III & $31.83 \pm 1.51^{b}$ & $48.33 \pm 1.86^{* *}$ \\
\hline & & IV & $33.50 \pm 1.12^{b}$ & $52.00 \pm 1.55 * *$ \\
\hline & \multirow{4}{*}{ Monocytes } & I & $3.83 \pm 0.17$ & $3.83 \pm 0.17$ \\
\hline & & II & $3.50 \pm 0.22$ & $4.00 \pm 0.00 *$ \\
\hline & & III & $3.67 \pm 0.21$ & $3.5 \pm 0.22$ \\
\hline & & IV & $3.67 \pm 0.21$ & $4.00 \pm 0.00$ \\
\hline & \multirow{4}{*}{ Eosinophils } & I & $5.00 \pm 0.00$ & $4.33 \pm 0.21 * *$ \\
\hline & & II & $4.67 \pm 0.33$ & $4.67 \pm 0.42$ \\
\hline & & III & $4.33 \pm 0.21$ & $4.00 \pm 0.26$ \\
\hline & & IV & $4.17 \pm 0.40$ & $3.83 \pm 0.31$ \\
\hline & \multirow{4}{*}{ Basophils } & I & $0.50 \pm 0.22$ & $0.17 \pm 0.17$ \\
\hline & & II & $0.33 \pm 0.21$ & $0.50 \pm 0.22$ \\
\hline & & III & $0.67 \pm 0.21$ & $0.33 \pm 0.21$ \\
\hline & & IV & $0.33 \pm 0.21$ & $0.50 \pm 0.22$ \\
\hline
\end{tabular}

* Significantly different from base values $(\mathrm{p}<0.05)$

** Significantly different from base values $(\mathrm{p}<0.01)$

Values with different superscripts differ significantly $(\mathrm{p}<0.05)$ among the groups

Fig.1 Recovery rate $(\%)$ in goats after different therapeutic management

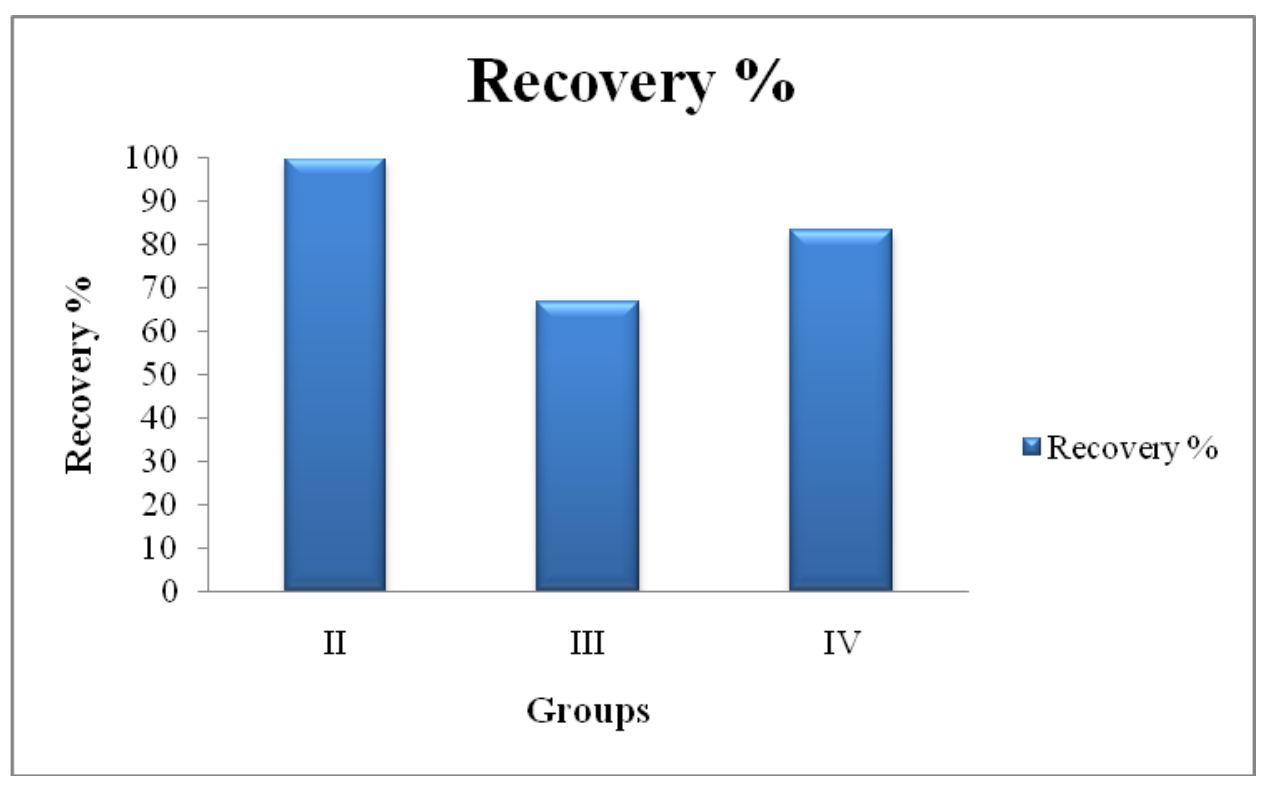


Table.3 Mean \pm S.E. value of biochemical parameters before and after different therapeutic management in goats

\begin{tabular}{|c|c|c|c|}
\hline \multirow[t]{2}{*}{ Parameters } & \multirow[t]{2}{*}{ Groups } & \multicolumn{2}{|c|}{ Day } \\
\hline & & 0 (before treatment) & 7 (after treatment) \\
\hline \multirow{4}{*}{$\begin{array}{l}\text { Serum Glucose } \\
(\mathbf{g m} / \mathbf{d l})\end{array}$} & I & $60.79 \pm 1.48^{\mathrm{a}}$ & $62.43 \pm 1.82$ \\
\hline & II & $52.18 \pm 1.57^{b}$ & $62.25 \pm 0.95^{* *}$ \\
\hline & III & $52.55 \pm 1.36^{b}$ & $60.61 \pm 1.13^{* *}$ \\
\hline & IV & $51.11 \pm 0.48^{b}$ & $60.00 \pm 0.51 * *$ \\
\hline \multirow{4}{*}{$\begin{array}{l}\text { Total serum } \\
\text { protein (g/dl) }\end{array}$} & $\mathbf{I}$ & $6.99 \pm 0.11^{\mathrm{a}}$ & $7.00 \pm 0.11^{\mathrm{a}}$ \\
\hline & II & $5.24 \pm 0.14^{b}$ & $6.96 \pm 0.08^{a^{* * *}}$ \\
\hline & III & $5.28 \pm 0.14^{b}$ & $6.64 \pm 0.12^{b^{* * *}}$ \\
\hline & IV & $5.29 \pm 0.18^{b}$ & $6.79 \pm 0.04^{a b^{* *}}$ \\
\hline \multirow{4}{*}{$\underset{(\mathrm{g} / \mathrm{dl})}{\text { Serum albumin }}$} & I & $3.62 \pm 0.08^{a}$ & $3.66 \pm 0.06^{\mathrm{a}}$ \\
\hline & II & $2.42 \pm 0.07^{b}$ & $3.69 \pm 0.03^{a^{* *}}$ \\
\hline & III & $2.43 \pm 0.07^{b}$ & $3.43 \pm 0.07^{b^{* * *}}$ \\
\hline & IV & $2.42 \pm 0.12^{b}$ & $3.60 \pm 0.02^{\mathrm{a}^{* * *}}$ \\
\hline \multirow{4}{*}{$\begin{array}{l}\text { Serum globulin } \\
\text { (mg/dl) }\end{array}$} & $\mathbf{I}$ & $3.36 \pm 0.04^{\mathrm{a}}$ & $3.34 \pm 0.06$ \\
\hline & II & $2.83 \pm 0.07^{b}$ & $3.27 \pm 0.06 * *$ \\
\hline & III & $2.85 \pm 0.07^{b}$ & $3.21 \pm 0.05 * *$ \\
\hline & IV & $2.87 \pm 0.09^{b}$ & $3.19 \pm 0.04 * *$ \\
\hline \multirow[t]{4}{*}{ A/G ratio } & I & $1.08 \pm 0.02^{a}$ & $1.10 \pm 0.02^{\mathrm{ab}}$ \\
\hline & II & $0.85 \pm 0.00^{b}$ & $1.09 \pm 0.01^{a b^{* *}}$ \\
\hline & III & $0.85 \pm 0.01^{b}$ & $1.06 \pm 0.01^{b * *}$ \\
\hline & IV & $0.84 \pm 0.04^{b}$ & $1.12 \pm 0.02^{\mathrm{a}^{* *}}$ \\
\hline \multirow[t]{4}{*}{ AST (units / L) } & I & $110.43 \pm 1.30^{b}$ & $111.35 \pm 1.38^{b}$ \\
\hline & II & $129.42 \pm 1.35^{\mathrm{a}}$ & $112.36 \pm 0.87^{b * *}$ \\
\hline & III & $130.98 \pm 1.42^{\mathrm{a}}$ & $116.83 \pm 0.30^{\mathrm{a}^{* * *}}$ \\
\hline & IV & $130.71 \pm 1.36^{a}$ & $115.27 \pm 0.39^{a^{* *}}$ \\
\hline \multirow[t]{4}{*}{ ALT (units / L) } & I & $32.32 \pm 0.92^{b}$ & $32.42 \pm 1.04^{b}$ \\
\hline & II & $39.52 \pm 0.62^{\mathrm{a}}$ & $33.99 \pm 0.11^{\mathrm{ab}^{* * *}}$ \\
\hline & III & $40.38 \pm 0.66^{a}$ & $34.67 \pm 0.25^{\mathrm{a} * *}$ \\
\hline & IV & $39.98 \pm 0.37^{\mathrm{a}}$ & $34.11 \pm 0.28^{\mathrm{ab}^{* * *}}$ \\
\hline
\end{tabular}

* Significantly different from base values $(\mathrm{p}<0.05)$

** Significantly different from base values $(\mathrm{p}<0.01)$

Values with different superscripts differ significantly $(\mathrm{p}<0.05)$ among the groups

The depletion of total serum proteins and serum albumin observed may be due to the utilization of blood proteins by organisms for their proliferation as well as decreased synthesis of proteins in the damaged liver during the disease process. Similar biochemical changes were also reported by Kaneko and Cornelius (1970),
Kumar et al., (1994) and Mandal et al., (2017) in goats. The hypoalbuminemia and hyperglobulinemia might be the cause of decreased $A / G$ ratio on day 0 in pneumonic goats. After administration of antibiotics, albumin and globulin values returned to normal values because of decrease in bacterial 
population and thus normal $\mathrm{A} / \mathrm{G}$ ratio was observed on day 7. Increase in enzymatic activity of Aspartate aminotransferase (AST) and Alanine aminotransferase (ALT) observed in the present study which might be due to inflammatory and degenerative changes in the organs (Nayak and Bhowmik, 1991).

\section{Recovery after therapeutic management}

The clinical recovery in pneumonic goats was assessed on the basis of improvement in clinical signs and restoration of the altered physiological parameters following different therapeutic management as shown in figure 1 .

In group II, all animals were recovered, however in group IV, 5 out of 6 and in group III, 4 out of 6 animals were completely recovered. The recovery rate of Ceftiofur sodium was highest followed by Enrofloxacin and Amoxicillin and sulbactum combination. Ceftiofur (thirdgeneration cephalosporin) are especially been developed for veterinary use. Ceftiofur has worldwide approvals for respiratory disease in swine, ruminants (cattle, sheep and goats) (Hornish and Katarski, 2002). Sargison and Scott (1995) have concluded that in general, newer antibiotics are more valuable than older ones for the treatment of respiratory disease, because long-standing use of latter agents increases the prevalence of microbial isolates to become resistant. On the basis of present study, it can be concluded that the administration of ceftiofur sodium was more efficacious as compared to enrofloxacin and amoxicillin and sulbactum combination for treatment of bacterial pneumonia in goats.

\section{References}

Ackermann, M.R. and Brogden, K.A. (2000). Response of the ruminant respiratory tract to Mannheimia (Pasteurella) haemolytica. Microbes and Infection, 2:1079-1088.

Aher, T.K., Roy, A. and Kumar, P. (2012). Molecular detection of virulence genes associated with pathogenicity of Gram positive isolates obtained from respiratory tract of apparently healthy as well as sick goats. Veterinary World, 5(11): 676-681.

Aytekin, I., Mamak, N., Ulucan, A. and Kalinbacak, A. (2011). Clinical, hematological, biochemical and pathological findings in lambs with Peste des Petits Ruminants. Kafkas University Veterinary Fak. Derg., 17(3): 349-355.

Bekele, T., Woldeab, T.A., Lahlou-Kassi, and Sherington, J. (1992). Factors affecting morbidity and mortality on-farm and onstation in the Ethiopian highland sheep. Acta Tropica, 52(2-3): 99-109.

Chakraborty S., Kumar,A., Tiwari, R., Rahal, A., Malik, Y., Dhama, K., Pal, A. and Prasad, M. (2014). Advances in Diagnosis of Respiratory Diseases of Small Ruminants. Veterinary Medicine International, 1-16.

Emikpe, B.O., Oyero, O.G., Akpavie, S.O. (2009). The isolation and antibiogram of aerobic bacterial nasal flora of apparently healthy West African dwarf goats. Revue d'Elevage et de Medecine Veterinaire des Pays Tropicaux, 62 (1): 17-21.

Garedew, L., Ayelet, G., Yilma, R., Zeleke, A., Gelaye, E. (2010). Isolation of diverse bacterial species associated with maedi visna infection of sheep in Ethiopia. African Journal Microbiology Research, 4:14-21.

Hornish, R.E. and Katarski, S.F. (2002). Cephalosporins in Veterinary Medicine Ceftiofur Use in Food Animals: A review article. Current Topics in Medicinal Chemistry, 2(7): 717731.

Jarikre, T.A., Emikpe, B.O., Ohore, O.G., Akinremi, T.A. and Akpavie, S.O. (2016). Bronchoalveolar lavage fluid cellular and haematological changes in different types of caprine pneumonia. Nigerian Journal of Physiological Sciences 31:31-36.

Kaneko, J.J. and Cornelius, C.E. (1970). Clinical 
Biochemistry of Domestic Animals (2nd edn.), Academic Press, New York and London.

Kumar, A., Verma, A.K., Gangwar, N.K., Rahal, A. (2012). Isolation, characterization and antibiogram of Mycoplasma bovis in sheep Pneumonia. Asian Journal of Animal and Veterinary Advances, 7(2): 149-157.

Kumar, H., Parihar, N.S., Kalicharan, K. and Singh, K.P. (1994). Pathology and bronchoscopic studies in contagious caprine pleuropneumonia subsp. mycoplasma infection in goats. Indian Journal of Animal Science, 64:9991005.

Kumar, S. (2007). Commercial goat farming in India: An emerging agri-business opportunity. Agricultural Economics Research Review. 20 (CI):503-520

Mandal, R.S.K., Gupta, V.K., Joshi, V., Surender, K. and Mondal, D.B. (2017). Study of clinico-Hemato-biochemical changes and therapeutic management of naturally infected cases of respiratory disease in non-descript goats of Bareilly region. International Journal of Livestock Research, 7 (6): 211-218.

Nayak, N.C. and Bhowmik, M. K. (1991). Pathogenicity of Mycoplasma mycoides subsp. mycoides (large colony type) for goat kids. Small Ruminant Research, 5(1-2): 155-167.

Rahman, T. and Singh, B. (1990). Clinicopathological features of pulmonary mycoplasma in goats. Indian Veterinary Journal, 67(10): 915-919.

Ramya, C.M. (2014). Bacterial Pneumonia. Research Journal of Pharmacy and
Technology, 7(8): 942-945.

Saleh, N. S., and Allam, T. S. (2014). Pneumonia in sheep: bacteriological and clinicopathological studies. American Journal of Research Communication, 2(11): 73-88.

Sargison, N.D. and Scott, P.R. (1995). Evaluation of antibiotic treatment of respiratory disease, including suspected septicemic pasteurellosis in five-weekold lambs. Agri-Practice. 16(10): 25-28

Sayed, A.S., Ali, A.A., Mottelib, A.A. and Abd El-Rahman A.A. (2002). Bronchopneumonia in buffalo- calves in Assiut governorate. Studies on bacterial causes, clinical hematological and biochemical changes associated with the disease. Assiut Veterinary Medicine Journal, 46(92): 138-155.

Snedecor, G.W. and Cochran, W.G. (1994). Statistical methods. Oxford and IBH Publications, Kolkota. pp.59

Travers, K. and Barza, M. (2002). Morbidity of infections caused by antimicrobialresistant bacteria. Clinical Infectious Diseases, 34(3): 131-134.

Woldemeskel, M., Tibbo, M. and Potgieter, L. N. D. (2002). Ovine progressive pneumonia (Maedi-Visna): an emerging respiratory disease of sheep in Ethiopia. Deutsche Tierarztliche Wochenschrift, 109(11):486-488.

Yener, Z., Ilhan, F., Ilhan, Z and Saglam, Y.S. (2009). Immunohistochemical detection of Mannheimia (Pasteurella) hemolytica antigens in goats with natural pneumonia. Veterinary Research Communication, 33: 305-313.

\section{How to cite this article:}

Rashmi S. Kashyap, H. K. Ratre, J. Singh, Rukmani Dewangan, C. Sannat, R. L. Rakesh, S. Chandrakar, S. Roy and Ali, S. L. 2019. Therapeutic Management of Bacterial Pneumonia in Goats in Durg District of Chhattisgarh State. Int.J.Curr.Microbiol.App.Sci. 8(12): 152-160. doi: https://doi.org/10.20546/ijcmas.2019.812.023 